FACTA UNIVERSITATIS

Series: Philosophy, Sociology, Psychology and History Vol. 17, Nº 3, 2018, pp. 189 - 198

https://doi.org/10.22190/FUPSPH1803189B

Review Paper

\title{
ON THE CONCEPT OF URBAN CITIZENSHIP
}

\author{
UDC 316.334 .56
}

\begin{abstract}
Jelena Božilović
University of Niš, Faculty of Philosophy, Department of Sociology, Niš, Serbia

Abstract. Urban citizenship is a frequent topic in studies in social sciences and it carries many different and ambiguous meanings. This paper is focused on the studies of urban citizenship as a type of the new concepts of citizenship, which is based on the idea that the city is a primary social and political community within which individuals and groups should exercise their rights. Contemporary demands for urban citizenship are mostly seen as a corrective of the neoliberal policy and unequal social power reflected on the use of space, and they are based on the viewpoint that a more inclusive policy is needed, which would include more citizens in decision making with regard to the (city) space. In this way, its pronounced commercial and consumer function would be reduced, and its use value would increase. In addition to urban citizenship being related to the idea of the right to the city at the theoretical and practical level, it is also based on the concept of citizenship (as a broader term under which it falls) and this paper also points to its variations.
\end{abstract}

Key words: urban citizenship, city, citizenship, the right to the city, new concepts of citizenship.

\section{INTRODUCTION}

"People make cities, but cities make citizens." Richard Rogers

The very idea of urban citizenship is not quite new, if we take into account Lefebvre's concept of the right to the city. In the 1960s, this author fought for expanding the rights that would accompany place of residence, i.e. be based on the principle of belonging and loyalty to the city. He starts from the point that class inequalities are basic social inequalities and that they can be overcome in the place of their greatest manifestation: within the city space. Therefore, the city is a central place of class conflict, so the struggle against such inequalities has to take place on city ground. A basic demand is that

Received May 16, 2018 / Accepted September 12, 2018

Corresponding author: Jelena Božilović

University of Niš, Faculty of Philosophy, Cirila i Metodija 2, 18000 Niš, Serbia

E-mail: jelena.bozilovic@filfak.ni.ac.rs 
everyone residing in a city must have the right to make decisions related to it: they are to be asked about the use (utilization) of the space, as well as about its production (Lefebvre 2008). Lefebvre's "formula" put this way allows an extension, in other words, in addition to the analysis from the perspective of class inequalities, it can be used for other diverse social groups and identities and their claim to the right to the city. Two interconnected challenges - globalization and multiculturalism - represent an especially significant context for contemporary deliberations on Lefebvre's postulates. They generate numerous problems, which are pointed to by different "repressed" actors, who want to affirm their values through claiming the right to the city. In each of these cases that can be studied (the right to the city of foreigners, gender inequalities, the LGBT perspective, ecological and other rights), the understanding that the city is a primary social environment of people is reactualized, and as such it has to be the central level of regulation of social relations, as well as the concept that the connection between the city and citizenship, although sometimes disturbed, is in fact unbreakable. This position is affirmed in the words of James Holston and Arjun Appadurai: "Although one of the essential projects of nation-building has been to dismantle the historic primacy of urban citizenship and to replace it with the national, cities remain the strategic arena for the development of citizenship" (Holston and Appadurai 2003, 296). From this, it becomes clear that, in addition to being based on Lefebvre's idea of the right to the city, urban citizenship is also derived from the concept of citizenship, so it can be said that urban citizenship is, actually, based on the synthesis of the two mentioned concepts.

Urban citizenship is frequently discussed within studies of citizenship, sociology, political geography and other social sciences. Nevertheless, it appears that the more this concept is used, the less it can be grasped, so sometimes its full meaning is not entirely clear. The confusion regarding the use of urban citizenship partly originates from the difficulties which follow the very term of citizenship, as a broader term into which urban citizenship falls. Historical transformations of citizenships and the figure of a citizen and their theoretical ambiguity (from Aristotle to contemporary conceptualizations) have indeed affected a certain kind of hypertrophy of the meaning of this term, enriching it, on the one hand, but also broadening it, on the other. In this sense, when we speak and write about citizenship today, we have different ideas and practices in our mind, from identifying citizenship with belonging to a state, to the understanding of citizenship as a concept that encompasses inhabitants of a city or a state, and finally to the notion according to which under the term of citizenship the concepts of civil rights, civil activism and various other phenomena are studied. This clearly shows that citizenship carries many different meanings, from formal and legal to ethical, and finally to those that can fall into the category of practice and activity.

\section{CitTZENSHIP AND URBAN CITIZENSHIP}

Falling under citizenship, urban citizenship is also burdened by perplexities and conceptual multivocality, thus reading papers dealing with this topic gives an impression of a rich and complex concept, but also, sometimes, not entirely clearly defined. In this paper, we rely on the understanding of urban citizenship as the concept of citizenship, which due to claiming the rights to the city by foreigners (immigrants) and various other social groups and identities, is based on the demand for greater autonomy of cities and in 
turn on the concepts of rights and duties. In order to define urban citizenship, we will use the meaning provided by Luis Eduardo Guarnizo, which sees the phenomenon of urban citizenship as that of citizenship which is located on the lower territorial scale, based on the idea of the right to the city, which originates as an inclusive response to neoliberalism and globalization (Guarnizo 2012, 15). Greater autonomy of cities, which would indeed need a more developed concept of urban citizenship (in the sense of the rights being delegated from the city), is seen today by many influential theorists as a necessary measure which could establish a certain balance between the needs and the rights of capital, on the one hand, and the needs and the rights of citizens, on the other. Different organizations, associations and movements for the right to the city mostly tend to level the present misbalances, so the presentation of their work is an important segment of the picture of the phenomenon of urban citizenship.

The demands that originate in the call for urban citizenship are frequently based on emphasizing legal spheres and formalization of the principle and relations of an individual towards a political community (in this case, a city), such as, for instance, the right to vote at the local level for non-citizens. However, studying the domain of the moral dimension of citizenship (emotional-identity dimension of citizens and its inherent values) indicate that the formal-legal framework (primarily that of belonging to a country) needs to be overcome by supplementing and expanding the right which results from other regulatory levels national, and indeed urban. Urban citizenship rests on this position, starting from the fact that, regardless of legal equality of all, social inequalities beyond the law overflow into the everyday life and reflect on the space that we inhabit; therefore, cities, being the most immediate environments in which an individual creates relationships and communicate, must be those political communities which are to have more significance in regulating civil rights through their decisions and regulations. What clearly follows is that the concept of urban citizenship is regarded as a collective of citizenship and belonging to a country. Therefore, being a citizen from this perspective means participating in the social life of a community, engaging, being an active member of the community and being asked about important decisions made in that community, and for something like that, formal citizenship (nationality or having a passport), is not sufficient. Moreover, it must not be the only criterion for regulating rights, because a large part of the city inhabitants (foreigners, i.e. immigrants) would be left out of the community and made non-citizens; this would not have positive effects not only on them, but also on the entire community. A solid community has to be built only through respect, acknowledgement and inclusion of all the citizens who live in a city, exactly as Lefebvre demanded it.

It should be emphasized that urban citizenship appears and is regarded as one of the new concepts of citizenships, ${ }^{1}$ more precisely, the one that emphasizes the importance of the territorial dimension of citizenship, i.e. territorial level or scale, which represents an actual political framework within which the entire dynamics of citizenship takes place. ${ }^{2}$ In the case of urban citizenship, the territorial scale, the importance of which is stressed,

\footnotetext{
${ }^{1}$ New concepts of citizenship are ideas that, by pointing to the shortcomings of the concept of citizenship based on the nation state, seek to find new citizen equalities, which would more closely correspond with the society of globalization, post-sovereignty and multiculturalism, and thus contribute to a fairer distribution of civil rights (See: Božilović 2012).

${ }^{2}$ The territorial level is also important for the analysis of many transnational concepts of citizenship (postnational, cosmopolitan, European, and others).
} 
is the city, as the basis of realization of the relation between an individual and the community (this does not negate other entities of belonging, such as national or supranational, they are complemented by this). ${ }^{3}$

\section{The Role of Cities AND URban Hegemony}

Urban citizenship is essentially connected with the issue of city autonomy as a political center within a wider political system. The idea that cities should have power comparable to that of a province is based on the fact that they are unified wholes with specific needs that cannot be entirely satisfied if they remain dependent on the state and regional centers of power. Broadbent, for instance, demonstrates on the example of Canadian cities how health and immigration policy are dependent on decisions of regional governments, although the dynamics in these social segments is significantly different in the cities from those at the regional level. Although they have economic power, cities are dependent on higher instances when it comes to political decisions, which hinder their progress (Broadbent 2009). The mentioned idea does not undermine the reason for the existence of the state community, nor does it call for its demise. It is rather an idea compatible with the principle of subsidiarity, a rational principle of decentralization, which grants greater autonomy to lower territorial levels (in this case cities) in relation to the provinces, state or supranational bodies, and is based on the idea that only those issues which the lower levels cannot effectively solve can be left to higher authorities (more in: Vujačić 2002). More broadly, subsidiarity sees its actors in individuals, as well as in associations, organizations and other local initiatives, believing that all of them can contribute to the local community and society with their strengths. Therefore, it begins with all social actors at the micro level and moves to wider governing structures that are at the top of the state or to supranational communities, such as the EU. ${ }^{4}$ The idea of urban citizenship finds inspiration in the principle of subsidiarity, because subsidiarity, as well as the concept of urban citizenship, rests on the assumption of a strong civil society as a counterpart to the state, that is, they are both in favor of establishing authorities from the bottom up (bottom-up principle) and they call for more society and less state.

Mark Purcell (2003) shares a similar understanding regarding the need for a larger role of cities in the context of thinking about the concept of citizenship. Thinking about the right to the global city, Purcell upgrades Lefebvre's concept by placing it into a contemporary context. Purcell speaks of three crucial changes (in inseparable and intertwined processes) which affect the concept of citizenship. Firstly, there is a rescaling of the social power, which moves from the national state to suprainstitutions (like the EU) and sublevels (regions, cities, boroughs). The second change is reterritorialization that weakens the territoriality and sovereignty of the nation state and sheds light upon the existence of many political loci and memberships. As the third change, Purcell mentions

\footnotetext{
${ }^{3}$ Urban citizenship emphasizes civic practices and affirms bottom-up policies. In contrast to urban citizenship, there are (static) models that make citizenship from top down, such as national and various types of transnational models.

${ }^{4}$ As a philosophical idea, subsidiarity also arises in Aristotle, who describes the state and the sense of the state using precisely this principle (Aristotle 2003, 3-6), while in the middle ages, subsidiarity is revived as the opposite of theories advocating a centralized state and absolutist power, such as in Hobs or Boden, and Johannes Althusius (see: Vujačić 2002) is a very important thinker who established it.
} 
reorientation, where many layers and multiplied identities blur the significance of national identity as the most important. These changes make the basic context which affirms the role of cities as the primary arenas of civil dynamics (Purcell 2003). Purcell considers urban citizenship as a concept of citizenship which should replace the dominant liberal-democratic form, through which the right to the city is given to international corporations, and diminished for the inhabitants of cities. The right to use the city space, as well as the right to participate in decision-making on the impact on the production of the space of a (global) city as a living space are directly endangered when the space is intended exclusively for consumerism without consulting citizens (Purcell 2003, 565579). ${ }^{5}$ Purcell believes that the solution for this conflict lies in the transfer of the power to decide from the state to the city, that is, he claims that it is necessary to replace the hegemony of the nation state with the model of urban hegemony, which confirms the importance of a territorial level for citizenship as such.

One way to correct the given social picture is the institute of the right to vote at the local level for non-citizens. Namely, a large number of immigrants who have legal residence in the countries of the West, after a certain number of years (which each country specifies independently, and it is often ten years), acquire citizenship and therefore political rights, above all the right to vote. ${ }^{6}$ By becoming citizens, they become an important target group of potential voters for politicians, whom they need to win over, and for that reason they frequently make favors. However, besides the integration at the national level, there are increasingly more initiatives for immigrants to obtain the right to vote at local elections, even if they do not have citizenship, but are legal inhabitants (non-citizen voting). Such practices, which fall under the political right to the city, have already been introduced in some places. For instance, in six cities of the state of Maryland this is already the case, and there are also examples in cities of Columbia, Ireland, New Zealand, Chile, and so on (in more than 26 countries). A special model of this kind has already been practiced in supranational communities, such as the EU and the British Commonwealth. However, it is believed that the introduction of this innovation in New York would have a special meaning in winning the political rights, since New York City frequently serves as a role model for other cities and countries in the world. The bill is currently under consideration, and it proposes that all city inhabitants obtain the right to vote at the local level, if they have legally lived in the city for at least six months. This act is justified, among other things, by the fact that many people without citizenship contribute, through their taxes and work, not only to the budget but also the better functioning of the city (no taxation without representation). Besides, it is rather clear that it those who live in a city and use its services that can also decide what needs to be changed, introduced, canceled and so on. The city has to belong to those who inhabit it, just like Lefebvre proclaimed.

Naturally, there are also counterarguments, which are mostly heard from republicans, but also from some intellectuals, who are concerned about the dignity of the institution of

\footnotetext{
${ }^{5}$ Purcell mentions an example by which citizens entitled to Los Angeles should have the right to participate in decision-making within a transnational corporation located in Chicago or any other city or state, because the operation of that corporation by relocation of capacities affects the space and lifestyle of Los Angeles citizens (Purcell 2003, 578).

${ }^{6}$ A program called Cities for Citizenship has been running for a long time in the United States, and its goal is to increase the number of foreigners with citizenship by facilitating the procedures for obtaining it, with cities having a key administrative and informative role in managing these programs (http://citiesforcitizenship.com/).
} 
citizenship. They believe that its reputation and significance has depreciated, because such easy access to the possibility of political participation sends the message that it is not important to put any effort into naturalization, that is, into the process of learning about the history, language and the culture of the USA, because one can also become a citizen without this effort. This, as they believe, undermines the very state and its sovereignty (https://www.theguardian.com/us-news/2015/apr/02/new-york-city-non-citizens-local-

elections). This debate is still ongoing, but it appears that the right to the city will win over the institution of citizenship in this case, that is, cities will gain autonomy in relation to the national context.

A similar campaign regarding the political right to the city has also been fought in Canada for quite a long time, since there is no consensus. The actors believe that the time of globalization and migrations has changed our understanding of participation and citizenship, and that urban citizenship is an idea that is quite suitable for a new global constellation of relations (Siemiatycki 2006; Steindorff 2014). Siemiatycki starts from a simple and accurate statement: "Local elections are the concern of local communities. Citizens without citizenship are members of the local communities who contribute to their development" (Siemiatycki 2006, 168). This is not the case in some political and philosophical fiction, but specific everyday issues which have to be resolved by the consensus or the will of the majority of members who make up a community. In some boroughs of Toronto, there are more than $30 \%$ of immigrants and they do not have voting rights when it comes to making decisions related to their particular borough. This hinders finding common solutions for issues that are of significance, specifically for a particular borough.

Charters on the right to the city also emphasize the idea that all who inhabit a city and its boroughs must have the right to political participation. They should be allowed to participate in local debates concerning the production of space, urban planning and improvement of the existing conditions in favor of citizens. It is preferable to affirm more frequent meetings of citizens in local communities, and especially to include marginalized groups (such as women) and immigrants in such activities. This demand falls under inclusive citizenship in the charters, which assumes equal rights to vote regardless of whether citizens permanently inhabit the city or are in transit (those who live in the city only temporarily). If a large number of citizens are excluded from making decisions, based on their ethnicity or formal status, this can seriously disintegrate the community, since it will not respond to the needs of the citizens, and decisions made in such a community will not reflect the real state of affairs. For that reason, the benefit of inclusive citizenship is huge, not only for those who are given the right to vote, but also for the entire city, which becomes a better integrated community by appreciating all of its inhabitants. Crime and other urban pathologies that are present in quarters dominated by immigrants can be reduced in this way, since instead of being marginalized, these people are offered a stronger sense of belonging and importance. In a broader sense, we can certainly state that the act of giving the right to vote at the local level contributes to stronger direct, participative democracy, which is a necessary mechanism for balancing, that is, for redistribution of social power in the time of neoliberalism. 


\section{PraCtice, ACTORS AND CONFLICTS}

The practice of urban citizenship assumes the study of social activism in the sense of the realization of the right to the city. A basic social context for such practices is neoliberal (urban) policy which produces conflicts between two opposing sides: the global economic elite and citizens who inhabit the city. Local institutions frequently favor the interests of capital, putting it before the needs of citizens, which is the reason for creating a specific social ambient filled with tension in which all entrepreneurial functions of the city take primacy over the social ones (Petrovic 2009). The tendency of neoliberal policy to revitalize these conflicts by promoting the ideology of consumerism and reducing citizens to consumers should be added, so even in the domain of the formation of urban citizenship (primarily at the conceptual and also at the practical level), the conflicts between the principles of cosmopolitism, the development of a multicultural global culture and the culture of consumerism become apparent.

There are many civil actors, represented by organizations and movements for the right to the city, who attempt to correct the mentioned "injustice". One of the more important organization is Right to the City Alliance, founded in 2007, whose aim is to extend racial, LGBT, ecological and other kinds of justice and democracy for all inhabitants. The activity of this organization is limited to the USA, i.e. it is a national association, but it is also mentioned that it has ambitions to act on a wider scale. During the first decade of this century, several conferences were held, some of which contributed to the formulation of the basic principles of the World Charter for the Right to the City. This and other declarations on the right to the city have a positive role, because they draw attention to different segments of the right to the city and vulnerable groups and identities with their systematic and normative approach and the call to solidarity. Their results are not huge, but they contribute to shedding some light on the issue of the right to the city and its importance in relation to civil rights. Besides movements and organizations, activities for promoting the right to the city are also conducted within some important global institutions. HABITAT conferences focused on all aspects of life in modern cities, current problems and networking of actors who could make their solutions possible. The HABITAT project was a part of the United Nations, and the last conference (HABITAT III) was held at the end of 2016 in Quito (Ecuador). The outcome of this large conference was the Urban Agenda, which contains a framework plan for city development in the next twenty years, i.e. until 2036, when a new conference, HABITAT IV is planned. The predominant topics include ecology, poverty, residence, immigration and other increasingly burning issues in the world.

Certainly, there are also other numerous organizations and projects which raise issues of the right to space, and from time to time, these battles are won. ${ }^{7}$ This is primarily the case with ecological rights, different minorities, LGBT and cultural rights, but also existential rights, when it comes to, for instance, the cases of poor citizens marginalized both in the social and spatial way. This palette of demands indicates the need to overcome the traditional Marxist approach, which places the working class in the focus of the struggle. Authors such as Harvey emphasize that all citizens today are affected in some way by capitalistic predatory practices, the effects of which are primarily felt in the city space

\footnotetext{
${ }^{7}$ More on different stories and studies on the right to the city in Remaking Urban Citizenship (2012).
} 
(Harvi 2013, 179). Therefore, all categories of citizens need to be studied in the sense of their capacities to act, instead of feeling remorse for the failure of the proletariat. ${ }^{8}$

However, there are numerous difficulties in the sense of realizing large changes regarding the right to the city and thus vitalizing the concept of urban citizenship. First and foremost, actors are fragmented and although they usually have the same interests, they are not directed to homogenous action. Harvey sees the reasons for their dispersion in the fact that they are still in the process of creation, but also in the fact that they are ideologically diverse and do not have political coherence. ${ }^{9}$ What is also important (but insufficiently present) is the networking of the urban projects between different cities and movements outside the borders of a single country. If this does not happen, what can be achieved at most are certain concessions by the government regarding reforms, but nothing of essence. The struggle, therefore, has to be persistent, networked, geographically spread and expanded to more territorial levels, whereby cities play the crucial role. In addition to fragmentation, antagonism is another obstacle which appears sometimes between actors who should be on the same side. In the context of neoliberal urban policy, a competitive atmosphere is created in which many actors fight, even aggressively, for self-promotion and fulfillment of their own rights, which produces new conflicts and does not contribute to the common good. Margit Mayer mentions a common example from the practice that urban movements consisting of middle-class citizens successfully prevent a certain facility from being built in their neighborhood, but as a result of it, a new location is found in a part of the city with poorer citizens, who have neither the capacity nor the social capital to fight for their rights (Mayer 2005, 291). Such and similar examples illustrate that problems related to the realization of the right to the city are frequently not solved, but only pushed from hand to hand without essential and lasting changes.

Criticism is also directed against organizations of civil society, which, although playing an important part when it comes to promoting interests of marginalized groups, are not always entirely efficient at solving urban problems. It can be heard that they are aimed only at finding instant solutions for the needs of marginalized groups, and that they contribute to the reproduction of ghetto economy, as well as that, instead of putting pressure on institutions, new old divisions are made within cities as a consequence of the activities of the NGO sector (Mayer 2005, 288). Having in mind the mentioned difficulties and the fact that even when they act together, movements and organizations hardly come into the field of official politics, obtaining the right to the city appears to be a complex and difficult task.

\section{CONCLUDING REMARKS}

A general conclusion indicates that acquiring the right to the city, as well as different practices which lead in that direction, tend to combine a formal-legal and a moral-

\footnotetext{
${ }^{8}$ Harvey thinks that it is necessary to abandon the traditional attitude of the working class as the one that will be the most important actor of change, because the industries in the world have fallen, and with them the traditional working class. Instead, today we have the precariat, as a low paid, temporary and unorganized urban workforce, which is why the importance of cities (instead of factories) as places of potential major social changes is growing.

${ }^{9}$ In a wider sense, reasons may also be sought in the lifestyles of individuals and social groups in metropolises, which are nothing but a daily strategy of survival (Petrović 2009, 177).
} 
axiological dimension, and they do this by affirming the latter, which is, as it is shown, often present. The disagreement between the normative and the real confirms that, although the national concept of citizenship (embodied in official citizenship) did have an emancipative role in the past, when applied to contemporary society shows many cracks and flaws. The supranational forms of regulatory bodies, their declarations and institutions can help in crossing this gap, since they communicate with citizens beyond nation states in their tendency to provide rights and dignities to them, but they are also not sufficient because they are too far removed from an individual and his or her everyday experience in their micro-environment. Because of that, urban citizenship, as the formula which enables communication between an individual and the city as the primary and immediate social and political environment of a person, could be a corrective that would fill in the gaps of citizenship and correct the flaws of a supranational mechanism for the protection of civil rights, which frequently look better on paper than in practice. The demands for urban citizenship assume that belonging to a country should be complemented by other types of regulations which are closer to everyday life, because that would allow a (urban) citizen to be asked, and to be given an opportunity to make decisions on resources and the space where he or she lives. For this reason, the claim for urban citizenship is nothing more than the struggle against democratic deficit through the expansion of the right to the space.

The prospect of this concept of citizenship, which is primarily based in cities, is largely dependent on civil activism. However, as it appears, a diversity of demands and the disconnection between actors indicate that the political dimension of citizenship has died out to some extent, because it was pushed back by the consumer society which produces the citizen-consumer as the dominant figure. Erich Fromm wrote about this phenomenon back in the 1950s, while describing an individual as alienated from all spheres of life, even from the civil society and the political sphere (From 2016, 133-138). The alienated, that is, depoliticized citizen becomes a good "subject" of the neoliberal consumer system, who can easily be manipulated, because their critical edge is taken from them. Based on what is said, the politicization of the citizen is one of the most important tasks in the direction of the correction of the system towards the creation of a just society, and politicization of the right to the city is the first and fundamental step towards this goal. It is understandable that engaged theory and social thought are not enough to create a political citizen, i.e. an interested and active individual. As Harvey says, the movement for the right to the city in the 1960s did not come from Lefebvre's theory, but from practice, i.e. everyday problems put by the government before citizens. Following Harvey's point, it can be expected that a further increase in contradictions, i.e. the polarizations which are produced by capitals, and the discontent of citizens will become larger and larger, until they finally peak in increasingly more frequent and massive urban insurgences, to which the political and economic elite could not turn a blind eye.

Acknowledgement: Prepared as a part of the project 179074 Tradition, Modernization and National Identity in Serbia and the Balkans in the Process of European Integration which is implemented by the Centre for Sociological Research, Faculty of Philosophy in Niš and funded by the Ministry of Education and Science of the Republic of Serbia. 


\section{REFERENCES}

Božilović, Jelena. "The Global City and Changes in the Concept of Citizenship". Facta Universitatis series: Philosophy, Sociology, Psychology and History 11, 1 (2012): 103-114.

Broadbent, Alan. (2009) Urban Nation. Canada: Harper Colins.

From, Erih. Zdravo društvo. Beograd: Kosmos izdavaštvo, 2016.

Guarnizo, Louis Eduardo. "The Fluid, Multi-scalar, and Contradictory Construction of Citizenship", In Remaking Urban Citizenship: Organisations, Institutions and the Right to the City. Volume 10: Comparative Urban and Community Research, edited by M. P. Smith, and M. McQuarrie, 11-39. New Brunswick and London: Transaction Publishers, 2012.

Harvi, Dejvid. Pobunjeni gradovi. Novi Sad: Mediterran Publishing, 2013.

Holston, James and Arjun Appadurai. (2003) "Cities and Citizenship", In State/Space, edited by N. Brenner, B. Jessop, M. Jones, and G. MacLeod, 296-309. Oxford: Blackwell Publishing.

Lefebvre, Anri. "Pravo na grad". U Priručnik za život u neoliberalnoj stvarnosti, uredili Kovačević i dr., 17-29. Zagreb: Savez za centar za nezavisnu kulturu i mlade, Multimedijalni institut, Platforma 9,81 - Institut za istraživanja u arhitekturi, Su Klubtura/Clubture, 2008. http://www.blok.hr/system/publication/pdf/7/PrirucnikZa-Zivot-u-Neoliberalnoj-Stvarnosti.pdf

Mejer, Margit. "Dalja upotreba pojma društvenog kapitala: uzroci i posledice po razumevanje gradova, zajednica i urbanih pokreta". U Urbana sociologija, uredili Mina Petrović i Sreten Vujović, 279-295. Beograd: Zavod za udžbenike i nastavna sredstva, 2005

Petrović, Mina. Transformacija gradova: ka depolitizaciji urbanog pitanja. Beograd: Institut za sociološka istraživanja Filozofskog fakulteta u Beogradu, 2009.

Purcell, Mark. (2003) "Citizenship and the Right to the Global City: Reimagining the Capitalist World Order", pp. 564-590. International Journal of Urban and Regional Research, Vol. 27.3.

Siemiatycki, Myer. "Invisible City: Immigrants without Voting Rights in Urban Ontario." Our Diverse Cities 4 (2006): 166-168.

Smith, Michael Peter, and McQuarrie, Michael, eds. "Remaking Urban Citizenship: Organisations, Institutions and the Right to the City". In Comparative Urban and Community Research, volume 10. New Brunswick and London: Transaction Publishers, 2012.

Steindorff, Alexandra. "Granting Non/Citzens the Right to Vote in Torronto's Municipal Elections". Public Policy and Governance Review 6, 1 (2014): 5-17.

Vujačić, Ilija. Politička teorija. Beograd: Čigoja štampa, 2002.

WEB

citiesforcitizenship.com

www.theguardian.com

\section{O KONCEPTU URBANOG GRAĐANSTVA}

Urbano građanstvo česta je tema istraživanja u društvenim naukama, ali isto tako i nosilac šarolikih i mnogostrukih značenja. U ovom radu fokus je na proučavanju urbanog građanstva kao jedne vrste novog koncepta građanstva, koja počiva na ideji da je grad primarna čovekova društveno-politička zajednica unutar koje pojedinci $i$ grupe treba da ostvaruju svoja prava. Savremeni zahtevi urbano građanstvo uglavnom posmatraju kao korektiv neoliberalne politike $i$ nejednake društvene moći koja se reflektuje na upotrebu prostora, te se baziraju na stavu da je potrebna inkluzivnija politika, koja bi u većoj meri uključila građane u donošenje odluka o (gradskom) prostoru. Na taj način bi se redukovala njegova prenaglašena komercijalna $i$ potrošačka funkcija, a povećala upotrebna vrednost. Pored toga što se na teorijskom i praktičnom nivou urbano građanstvo povezuje sa idejom prava na grad, ono se utemeljuje $i$ u pojam građanstva (kao širi pojam kome pripada), na čije varijacije se u radu takođe ukazuje.

Ključne reči: urbano građanstvo, grad, građanstvo, pravo na grad, novi koncepti građanstva. 